\title{
The effect of fat composition of the diet on energy metabolism.
}

Citation for published version (APA):

van Marken Lichtenbelt, W. D., Mensink, M. R., \& Westerterp, K. R. (1997). The effect of fat composition of the diet on energy metabolism. Zeitschrift für Ernahrungswissenschaft, 36(4), 303-305.

https://doi.org/10.1007/BF01617803

Document status and date:

Published: 01/01/1997

DOI:

10.1007/BF01617803

Document Version:

Publisher's PDF, also known as Version of record

Document license:

Taverne

Please check the document version of this publication:

- A submitted manuscript is the version of the article upon submission and before peer-review. There can be important differences between the submitted version and the official published version of record.

People interested in the research are advised to contact the author for the final version of the publication, or visit the DOI to the publisher's website.

- The final author version and the galley proof are versions of the publication after peer review.

- The final published version features the final layout of the paper including the volume, issue and page numbers.

Link to publication

\footnotetext{
General rights rights.

- You may freely distribute the URL identifying the publication in the public portal. please follow below link for the End User Agreement:

www.umlib.nl/taverne-license

Take down policy

If you believe that this document breaches copyright please contact us at:

repository@maastrichtuniversity.nl

providing details and we will investigate your claim.
}

Copyright and moral rights for the publications made accessible in the public portal are retained by the authors and/or other copyright owners and it is a condition of accessing publications that users recognise and abide by the legal requirements associated with these

- Users may download and print one copy of any publication from the public portal for the purpose of private study or research.

- You may not further distribute the material or use it for any profit-making activity or commercial gain

If the publication is distributed under the terms of Article $25 \mathrm{fa}$ of the Dutch Copyright Act, indicated by the "Taverne" license above, 
"W. D. van Marken Lichtenbelt

R. P. Mensink

K. R. Westerterp

\section{The effect of fat composition of the diet on energy metabolism}

Einfluß der Fettzusammensetzung der Nahrung auf den Energieumsatz

Summary Animal and human studies show that polyunsaturated fatty acids $(\mathrm{P})$ are oxidized more rapidly than saturated fatty acids (S). There are indications that diets high in $\mathrm{P} / \mathrm{S}$ ratio result in a relatively high resting metabolic rate (RMR) and high diet induced thermogenesis (DIT). However, studies with human subjects are limited.

The effect of dietary fatty acid composition on energy metabolism was studied in 6 male subjects, age 25-48 y. Two diets were supplied, each over a period of 14 days, in a randomized crossover design with a washout period of 14 days. $\mathrm{P} / \mathrm{S}$ ratios of the diets were 0.19 and 1.67 .
On day 14 , RMR was determined in the morning in fasting state by means of indirect calorimetry (ventilated hood), followed by a 4 hour measurement of the DIT after consumption of a standardized meal of 3.3 MJ with the same fatty acid composition as during the dietary period. The meal contained 46,37 , and $17 \%$ energy as fat, carbohydrate, and protein, respectively.

RMR after the period with the high P/S diet was significantly higher than after the period of the low $\mathrm{P} / \mathrm{S}$ diet. The average difference $( \pm \mathrm{SD})$ was $0.17 \pm 0.14$ $\mathrm{kJ} / \mathrm{min}$ or $3.6 \pm 2.7 \%$ of RMR.

The DIT was also higher in all subjects during a breakfast with a high $\mathrm{P} / \mathrm{S}$ ratio. The average difference was $0.29 \pm 0.16 \mathrm{~kJ} / \mathrm{min}$, which is $22.1 \pm 12.6 \%$ of DIT.

The study showed that a prolonged food intake of a diet with a high $\mathrm{P} / \mathrm{S}$ ratio results in a relatively high RMR and DIT. These results indicate the importance of dietary lipid profile in the treatment of obesity.

\section{Zusammenfassung Untersuchun-} gen an Tieren und am Menschen zeigen, daß polyungesättigte Fettsäuren $(\mathrm{P})$ schneller als gesättigte Fettsäuren (S) oxidiert werden. Es gibt Hinweise dafür, daß Diäten mit einem hohen $\mathrm{P} / \mathrm{S}$-Verhältnis einen re- lativ hohen Ruheenergieumsatz (RMR) und eine hohe diät-induzierte Thermogenese (DIT) verursachen. Untersuchungen beim Menschen sind jedoch begrenzt. Die Effekte der NahrungsfettsäurenZusammensetzung auf den Energieumsatz wurden bei 6 männlichen Personen (Alter 25-48 Jahre) untersucht. In einer randomisierten Crossover-Studie wurden 2 Diäten über eine Zeitperiode von $14 \mathrm{Ta}$ gen mit einer anschließenden washout-Periode verabreicht. Das P/S-Verhältnis betrug bei diesen Diäten 0,19 und 1,67. RMR wurde am 14. Tag früh im Nüchternzustand mittels indirekter Kalorimetrie (ventilierte Haube) bestimmt. Daran schloß sich nach Aufnahme einer standardisierten Mahlzeit mit einem Energiegehalt von 3,3 MJ (gleiche Fettsäuren-Zusammensetzung wie während der Diätperiode) eine $4 \mathrm{~h}-\mathrm{Messung}$ der DIT an. Die Mahlzeit enthielt 46, 37 und 17 Energie\% an Fett, Kohlenhydrate und Protein. RMR war nach der Periode mit hohem P/S-Verhältnis signifikant höher als nach der Periode mit niedrigem P/S-Verhältnis. Die mittlere Differenz betrug $0,17 \pm 0,14$ (SD) $\mathrm{kJ} / \mathrm{min}$ bzw. $3,6 \pm 2,7 \%$ von RMR. DIT war bei allen untersuchten Personen während eines Frühstuicks mit einem hohen P/S-Verhältnis höher. Die mittlere Differenz betrug $0,29 \pm 0,16$ (SD) $\mathrm{kJ} / \mathrm{min}$ bzw. $3,6 \pm 2,7 \%$ von DIT. Die Untersuchung zeigt, daß 
eine prolongierte Aufnahme einer Diät mit einem hohen $\mathrm{P} / \mathrm{S}$-Verhältnis $\mathrm{zu}$ relativ hohem $\mathrm{RMR}$ und DIT führt. Diese Ergebnisse weisen auf die Bedeutung des Nahrungsfettprofils bei der Behandlung der Fettsucht hin.
Key words Energy metabolism diet - fat composition - fatty acids - thermogenesis - obesity indirect calorimetry
Schlüsselwörter Energieumsatz Diät - Fettzusammensetzung -

Fettsäuren - Thermogenese -

Adipositas - indirekte Kalorimetrie

\section{Introduction}

To date, emphasis with regard to weight balance has been placed on the amount of fat in the diet, while the role of fat composition on substrate metabolism and balance has often been ignored. Previous studies $(1,2)$, however, suggest that the degree of unsaturation of dietary long chain fatty acids influences the partitioning of fat between oxidation and storage. Animal (3) and human (1, 4) studies show that polyunsaturated fatty acids (P) oxidize more rapidly than saturated fatty acids (S). A high $\mathrm{P} / \mathrm{S}$ ratio results in a relatively high resting metabolic rate (RMR), high diet induced thermogenesis (DIT), and higher fat oxidation (5). A recent study confirms that a significant increase of whole body oxidation of longchain fatty acids occurs with a diet high in polyunsaturated fat compared to one high in saturated fat (6). These results may be explained by a more efficient absorption of PUFA's (7), preferential transport by the portal circulation (6), and/or a more rapid divertion into pathways of keton body production compared to the unsaturated fatty acids (5). The increased fat oxidation following a meal high in PUFA's was not completely compensated for by a reduction in carbohydrate oxidation (5). It is remarkable that hardly any studies followed that focussed on these phenomena.

This study, therefore, aims at investigating the effect of dietary fatty acids composition in the diet on resting energy expenditure and diet induced thermogenesis.

\section{Materials and methods}

The effect of dietary fatty acid composition on energy metabolism was studied in 6 male subjects, age $25-48 \mathrm{y}$. Two diets were supplied, each over a period of 14 days, in a randomized crossover design with a washout period of 14 days. $\mathrm{P} / \mathrm{S}$ ratios of the diets were 0.19 and 1.67 (Fig. 1).

After the 14 day dietary period fasting blood samples were taken in which serum fatty acids profile and cholesterol were determined. On day 14, RMR was determined in the morning in fasting state by means of indirect calorimetry (ventilated hood), followed by a 4 hour measurement of the DIT after consumption of a standardized meal of 3.3 $\mathrm{MJ}$ with the same fatty acid compo-

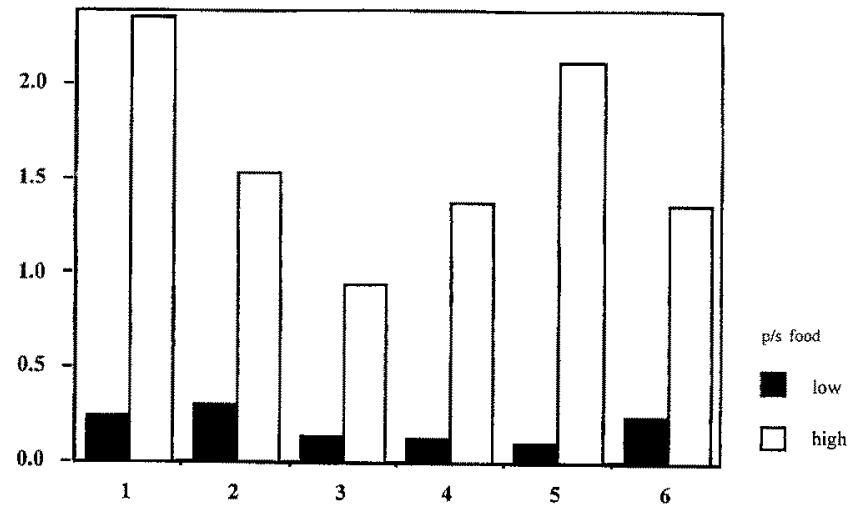

Fig. $1 \mathrm{P} / \mathrm{S}$ ratio in the food during the dietary periods in the different subjects.

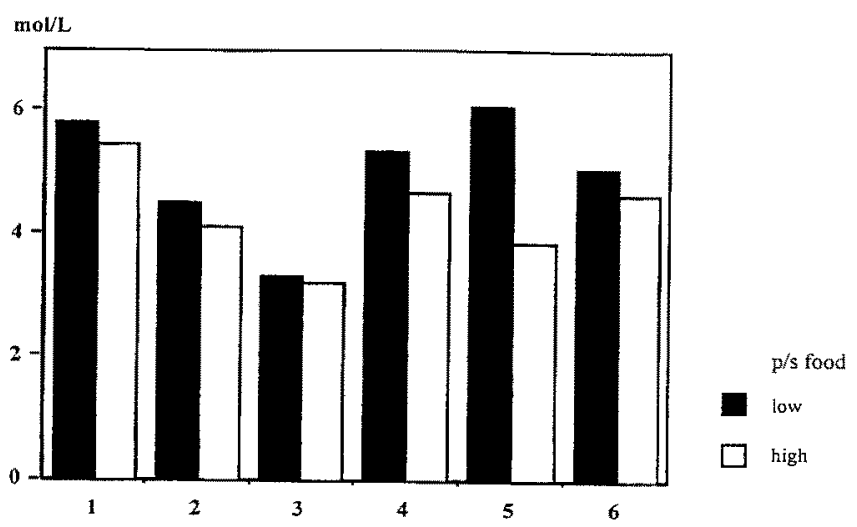

Fig. 2 Serum cholesterol levels in each subject during different dietary regimes.

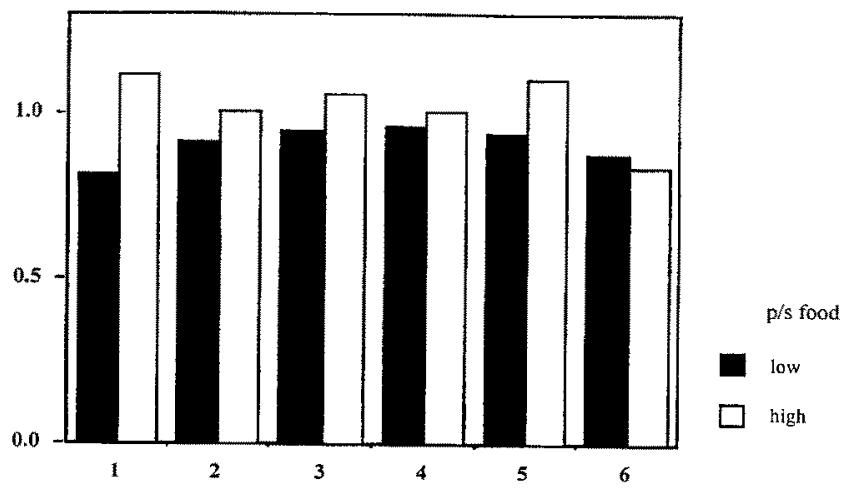

Fig. 3 Serum P/S ratio in each subject during different dietary regimes 


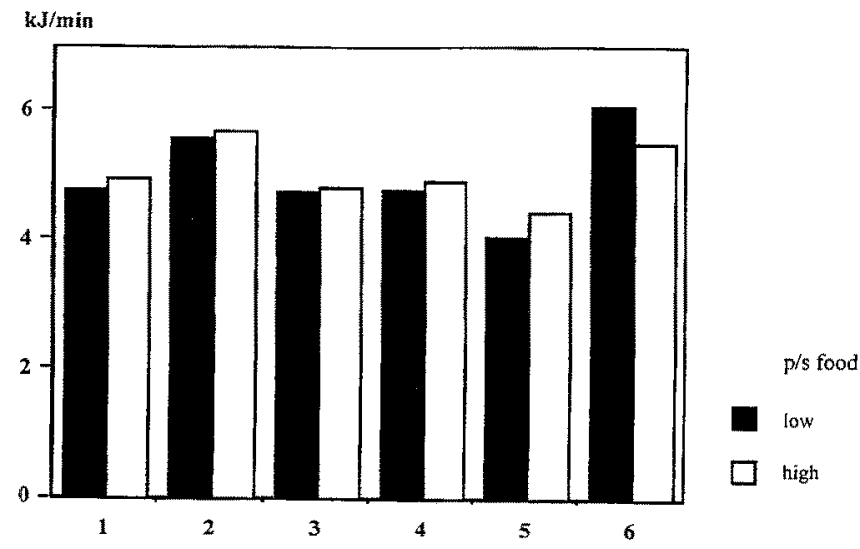

Fig. 4 Resting metabolic rates as measured in individual subjects after the two dietary periods.

sition as during the dietary period. The meal contained 46,37 , and $17 \%$ Energy as fat, carbohydrate, and protein, respectively.

\section{Results}

In all subjects serum cholesterol levels were elevated after the dietary period with a low $\mathrm{P} / \mathrm{S}$ ratio compared to the high P/S ratio (Fig. 2). P/S ratio in serum was significantly higher after the dietary period with fats with the high P/S ratio (one exeption, Fig. 3).

RMR after the period with the high P/S diet was significantly higher than after the period of the low P/S

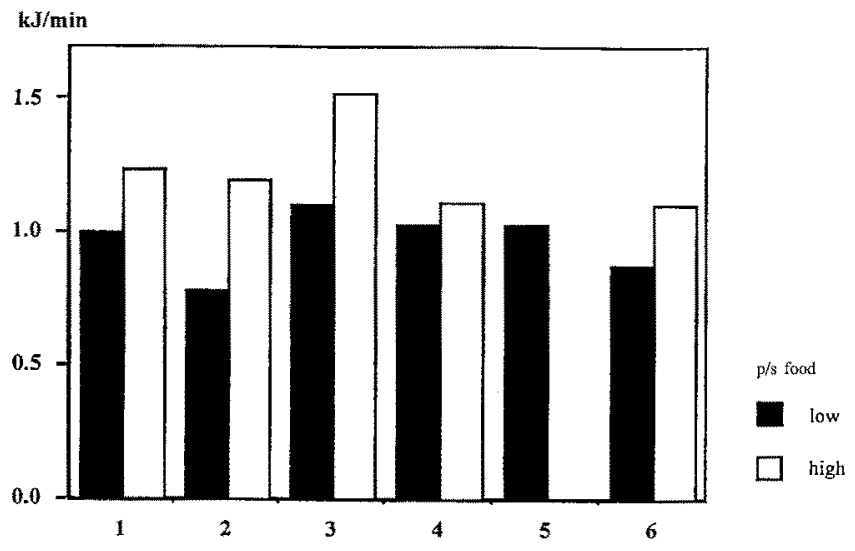

Fig. 5. Diet induced thermogenesis as measured in individual subjects after the two dietary periods.

diet with one execption (Fig. 4). The average difference was $0.17 \pm 0.14 \mathrm{~kJ} / \mathrm{min} \pm \mathrm{SD}$, or $3.6 \pm 2.7 \%$ of $\mathrm{RMR}$. The DIT was also higher after a breakfast with a high P/S ratio (Fig. 5). The average difference was $0.29 \pm 0.16$ $\mathrm{kJ} / \mathrm{min}$, which is $22.1 \pm 12.6 \%$ of DIT.

\section{Conclusion}

The study shows that a prolonged intake of a diet with a high P/S ratio results in a relative high RMR and DIT. These results indicate the importance of dietary fatty acids composition on substrate utilization.

\section{References}

1. Jones PJH, Pencharz PB, Clandinin MT (1985) Whole body oxidation of dietary fatty acids: implications for energy utilization. Am J Clin Nutr 42:769-77

2. Pan DA, Hulbert AJ, Storlien LH (1994) Dietary fats, mebrane phospholipids and obesity. J Nutr 124:1555-65

3. Leyton J, Drury PJ, Crawford MA (1987) Differential oxidation of saturated and unsaturated fatty acids in vivo in the rat. Brit $J$ Nutr 57:383-93
4. Emken EA (1994) Metabolism of dietary stearic acid relative to other fatty acids in human subjects. Am J Clin Nutr 60:1023S-8

5. Jones PJH, Schoeller DA (1988) Polyunsaturated:saturated ration of diet fat influences energy substrate utilization in the human. Metabolism 37:145-51

6. Clandinin MT, Wang LCH, Rajotte RV, French MA, Goh YK, Kielo ES (1995) Increasing the dietary polyunsaturated fat content alters whole-body utilization of 16:0 and 10:0. Am J Clin Nutr 61:1052-7
7. Cunningham KM, Daly J, Horowitz $M$, Read NW (1991) Gastrointestinal adaptation to diets of differing fat composition in human volunteers. Gut $32: 483-6$ 